\title{
Turkmen Language
}

National Cancer Institute

\section{Source}

National Cancer Institute. Turkmen Language. NCI Thesaurus. Code C154178.

A T urkic language spoken as an official language of Turkmenistan. 